\title{
WHEN CRISIS IS EXPERIENCED AS CONTINUITY. MATERIALITIES OF TIME IN HAITI
}

\author{
Erin B. Taylor \\ Presses Universitaires de France | Ethnologie française
}

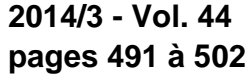

ISSN 0046-2616

Article disponible en ligne à l'adresse:

http://www.cairn.info/revue-ethnologie-francaise-2014-3-page-491.htm

Pour citer cet article :

Taylor Erin B., « When Crisis Is Experienced as Continuity. Materialities of Time in Haiti », Ethnologie française, 2014/3 Vol. 44, p. 491-502. DOI : 10.3917/ethn.143.0491

Distribution électronique Cairn.info pour Presses Universitaires de France.

(c) Presses Universitaires de France. Tous droits réservés pour tous pays.

La reproduction ou représentation de cet article, notamment par photocopie, n'est autorisée que dans les limites des conditions générales d'utilisation du site ou, le cas échéant, des conditions générales de la licence souscrite par votre établissement. Toute autre reproduction ou représentation, en tout ou partie, sous quelque forme et de quelque manière que ce soit, est interdite sauf accord préalable et écrit de l'éditeur, en dehors des cas prévus par la législation en vigueur en France. II est précisé que son stockage dans une base de données est également interdit. 


\section{When Crisis Is Experienced as Continuity. Materialities of Time in Haiti}

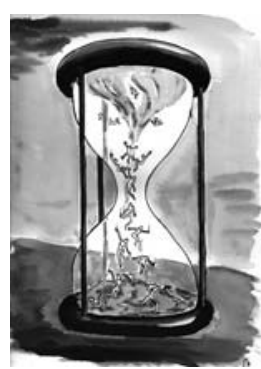

Erin B. Taylor

Instituto de Ciências Sociais

Universidade de Lisboa

\section{RÉSUMÉ}

L'expérience de la crise comme continuité. Les usages matériels du temps en Haïti.

Cet article explore les manières dont le temps est vécu et utilisé par les Haïtiens vivant à la frontière avec la République Dominicaine. En examinant différentes formes de pratiques temporelles et les représentations qui y sont attachées, l'auteur interroge le présupposé qui voudrait que le tremblement de terre de janvier 2010 ait signifié une rupture brutale avec le passé et montre que fa crise en Haïti ne constitue pas une coupure historique unique, mais une caractéristique constante de l'expérience historique. La façon dont les biographies personnelles sont contées et le futur envisagé reflètent ces continuités.

Mots-clés : Temps. Modernité. Crise. Caraibes. Haiti.

Erin B. Taylor

Instituto de Ciências Sociais

Avenida Aníbal Bettencourt, 9

Universidade de Lisboa

Lisboa, 1600-189

Portugal

erin@erinbtaylor.com

Catastrophe has a way of splitting time in two. Since a 7.0 magnitude earthquake hit Haiti on January 12, 2010 , this small island nation's history is often referred to by academics, NGOs, and policy makers as comprising the period "before the earthquake" and "after the earthquake" [Farmer, 2012; Schuller, 2012]. The magnitude of the disaster appears to merit this temporal split: resulting in tens of thousands of deaths and millions of people displaced from their homes, the trauma of the earthquake will not easily be forgotten. Moreover, the desire of the international community to "build back better" signals an intent that the earthquake will indeed represent a significant break from the past, one that will finally result in significant socio-economic development for the western hemisphere's poorest nation.

And yet, it is worth stopping to ask, to what extent does this temporal narrative reflect personal experiences of time in Haiti? Is this division between pre-and post-earthquake Haiti simply a new iteration of a long history of temporal categorization by outsiders? After all, Caribbean societies have long been represented in two opposing ways: primitive and ahistorical, or modern and globalized. Allochronic representationsdepicting a people as living in the past [Fabian, 1983] are a crucial part of branding the Caribbean to drive tourism and fuel the economic growth that permits many small nations to keep pace with global change. But the Caribbean is not always rendered as primitive: on the contrary, studies of Caribbean societies often emphasise the region's early modernity, its central role in the history of globalization, and processes of creolization. These foci emphasise change and coevalness. Which, if any, of these representations of time are relevant to the lives and experiences of Haitians?

In this paper, I explore various ways in which time is experienced and practised by Haitians living on the Dominican-Haitian border. By examining different kinds of temporal practices and viewpoints, I demonstrate how time as lived experience and time as narrative are interrelated. As such, they are co-created by a range of social actors, including social commentators, nation-states, and citizens. I question the assumption that crisis has brought a significant break with the past, either due to its disruptive nature or as a bell-weather for a new era of change. When people experience life 
as a series of crises, crisis becomes a constant feature of the historical experience, rather than an isolated and unique rupture. The ways that people communicate their biographies and imagine their futures reflect this temporal continuity.

Viewing crisis as a constant problematizes the question of how the ethnographer can understand a moment of disruption when their fieldwork takes place after the event has passed. I argue that, far from the moment of crisis being finished, it is plural and visible in people's everyday lives, especially in relation to their productive and consumptive activities. Experiences of crisis and coping with uncertainty are often experienced in material ways, such as losing one's home in a natural disaster, disruption to trade cycles, or migration. Consumption and production are used to mitigate the risk of experiencing crises and cope with them when they occur. The fabric of social time, particularly for people living in uncertain circumstances, thereby incorporates historical consciousness, expressed through biographies, with ever-changing contemporary experiences. These are observable far beyond the particular moments in which crises take place, because understandings of events and change are constructed by individuals with reference to multiple moments in time.

\section{- Time in the Caribbean}

Island societies occupy a distinctive place in geographic imaginaries. Their clear blue waters, coconut trees, and brown-skinned residents have been represented as timeless and unchanging in countless works of art, fiction, and ethnography. From Gauguin's paintings of Tahitian women, to resort brochures depicting performances of 'traditional' culture on sandy Dominican beaches, islands act as symbols of escape from the stresses of the modern world to a time of greater purity and tranquillity. These allochronic representationsof people living in a different time-are a crucial part of branding the Caribbean to drive tourism and fuel the economic growth that permits many small nations to keep pace with global change [see Gregory 2007]. In other words, primitivism assists in keeping the Caribbean modern.

Yet these images of paradise have a darker side. Not only are they unrealistic, obfuscating half a millennium of modernity in the Caribbean, but they can also have negative political and social consequences. Haiti is arguably the most archetypal example of a Caribbean nation with a temporal branding problem, as it struggles to shake off images of itself as backwards and primitive. Over the past few centuries, a series of political and natural crises have seen Haiti repeatedly cast by news media, national governments, and publics as a nation-state that is stuck in a dysfunctional past, a "failed state" whose people are superstitious and therefore not able to fully function in the modern world. Timeless creatures such as zombies and vodou gods, rather than rock stars or politicians, are held up as icons of Haitian cultural life.

Promulgated by both locals and foreigners, this negative temporal reading circumscribes belief that a better future is possible. Since the earthquake of January 12, 2010, hopes for Haiti's future have improved somewhat as international focus has shifted towards "fixing" Haiti. While an injection of foreign aid, expertise, and optimism is a positive step, however, the international presence threatens to handicap efforts to capacitate Haitians to resolve their own problems [Farmer, 2012]. This exacerbates its dependency on international institutions and feeds the cycles of political instability and civilian unrest that underlie Haiti's problematic march towards socio-economic development.

While there is certainly a genre of Caribbean anthropology that focuses on primitivism or tradition, such as vodou in Haiti [Zora Neale Hurston, 2009] or the practice of folklore in the Dominican Republic [Andrade, 1969], the region's long engagement with modernity and change makes it a dubious fit with the "savage slot" in anthropology [Trouillot, 2003]. Early studies of Caribbean social life searched for tradition in retentions of African culture, yet even these studies were oriented more towards understanding how syncretic cultural practices involved rupture with the past [Herskovits, 1938, 1972; Mintz and Price, 1985; Trouillot 1995]. Trouillot [2003] puts anthropological theory into historical perspective, arguing that lack of recognizable "tradition" in the Caribbean prompted the critique of anthropology's focus on the "savage slot." Because the region's indigenous population was decimated by the 1530s, there was no "traditional" society left to describe. Neither Western enough for sociological investigation, nor traditional enough for anthropology, the region was relatively neglected as an object of study until the mid-twentieth century.

A shift in scholarly approach to the Caribbean occurred when modernity became an object of 
interest. Since the fifteenth century, Haitian society and economy have been characterised by a temporal modernity of a kind that is generally not referenced in popular representations of Haiti. Melville Herskovits [1937] and Sidney Mintz [1962, 1979] were two of the earliest anthropologists to recognise the modern features of Caribbean life. Working in Haiti since the 1950s, Mintz described Haitian agricultural labourers as proletarians, rather than as peasants who were living a traditional lifestyle. He argued that, far from being new to modernity, Haiti's economic features make it one of the earliest "modern" societies in the world:

Long before the common features of the industrial West (imported foods, time-conscious work regimes, factory production, impersonal work relations, etc.) had spread through much of Europe, they were commonplace aspects of life for Caribbean slaves [.....] Accustomed to ethnic and cultural differences, to the movement of peoples into (and out of) their midsts, to migration itself as a way of life, to industrial tempos imposed on agricultural economies, and to the common contrasts between the lives of the privileged and the lives of the poor, Caribbean folk often seem more prepared for the modern world than other so-called Third World peoples. [Mintz, 1985: 9-10]

Despite its early foray into modernity, Haiti failed to keep pace with developments around the globe [see Farmer 2004]. Haiti's economic booms in the 1950s and 1980s, based largely on tourism, were undermined by political unrest, competition elsewhere in the Caribbean, and a series of natural disasters culminating in the January 12, 2010 earthquake that seemed to prove Marshall Berman's observation (paraphrasing Marx) that, in modernity, "all that is solid melts into air" [1982]. Even before the earthquake, Port-au-Prince was in a state of decay, testimony to the fact that the passage of time does not necessarily bring material progress.

Given the coexistence of tradition and modernity, it is not surprising that allochrony and coevalness are so often represented simultaneously in depictions of Haiti. Indeed, Aisha Khan [2001] suggests that the Caribbean region has been adopted as a global metaphor for processes of change due to the particularly striking ways in which elements of tradition and modernity are juxtaposed. She writes, "Depicted today as uncertain, variegated, and unfinished-as creole - the world seems to have found its emblem in the Caribbean" [ibid.: 271]. Haiti is no exception: cultural anthropology emphasizes Haiti's creolité, while socio-economic development experts and policy makers describe Haiti as a work in progress. These narratives have only grown in frequency since the earthquake, whose destruction enhanced this perception of unfinishedness.

Comprised of multiple social, cultural, and economic influences that have been jostling for position for centuries, the Caribbean is a "master symbol" of the process of globalization. Yet this idea of an unfinished world, comprising tradition, modernity, and change, is more than a metaphor harnessed by outsiders: it is also experienced by people living in the Caribbean. Our role as ethnographers, then, may be not to promote coevalness over allochrony, but to understand how temporal categories underwrite both Caribbean social life and its use by outsiders as a metaphor for temporal processes such as change and modernity.

Ethnographies of the Caribbean have focused on a variety of cutting-edge issues, such as creolization [Khan, 2004], globalization [Gregory, 2007], migration [Glick-Schiller, 2001], employment [Yelvington, 1995], technology [Horst and Miller, 2006], and informal transnational traders [Ulysse, 2008]. These studies have generated some interesting theoretical observations about temporal consciousness and its effects on social structure. In particular, Daniel Miller [1994] argues that in Trinidad, and the Caribbean more broadly, modernity has resulted in a dualism of "transience" and "transcendence." In his account, modernity is characterized by a temporal consciousness of ephemerality (transience), but also by a search for rootedness, found in traditions (transcendence). This split does not inevitably result in the appearance of dualism everywhere around the globe; rather, it appeared in the Caribbean due to the region's intensive experiences of the processes of change. The institution of slavery produced intense social alienation and rupture when people from various parts of Africa were transported to the Americas, where they recreated social and cultural practices under conditions of domination. In more contemporary times, Miller relates how, in Trinidad, a sense of rapid change and insecurity was augmented by the rapid growth and demise of oil boom (circa 1976-1983).

Contra Marx, Miller argues that alienation and rupture are not the outcome of being divorced from the products of one's labour. Rather, alienation should be understood in terms of a rupture of temporal consciousness that is reconciled through consumption. Rapid change and the experience of transience limit 
people's ability to depend upon social relations in shaping their identities. As a result, values and meanings are increasingly objectified in things rather than social relationships. Miller writes that Trinidadians have developed a unique national identity that is based on ethnic dualism and realized through consumption. Trinidadians reconcile this dualistic split by using consumer goods to promulgate traditions, while engaging in transience through the display of personal style, often influenced by transnational relations. Consumption is able to fulfil this role because objectifications of the self in material form can simultaneously express both tradition and change.

Miller's observations about the bases of dualism hold for Haiti and the Dominican Republic, where ongoing crises exacerbate this sense of rupture and the dual search to take advantage of modernity and find a secure place within it. However, while consumption is certainly implicated in reconciling tradition and change, my research indicates that consumption is not the only sphere through which people experience, or resolve, the temporal contradictions of modernity as they are created and recreated by multiple social actors. Different kinds of production, such as of goods or national identities, also involve the strategic deployment of temporal consciousness to create social hierarchies or to harmonize social contradictions. In the following sections I draw upon my own ethnographic research to demonstrate how these practices of production and consumption intertwine.

\section{- Stripped of time}

Sandra is a young woman from Port-au-Prince who has lived with her family in Pedernales, on the border of the Dominican Republic and Haiti, for the past two years. Her family took refuge in the border region after the earthquake. When the earthquake hit, Sandra was living with her family in Pétionville, Haiti. She recounted to me with great sadness how she survived, but her sister died when a portion of their home fell down. She recalls seeing bodies everywhere on the street, and feeling shocked that the world around her could be destroyed so abruptly. Her family spent a month sleeping in a local park. They decided to relocate to Anse-à-Pitres, 155 kilometres away, because they had family there, including one of Sandra's sisters (who had married a Dominican) and two of her cousins. Sandra's mother had visited the Dominican Republic previously, but the rest of the family had not. Her mother did not like Anse-à-Pitres, however, so after six months the family moved two kilometres across the border to Pedernales. They obtained Dominican visas and have now resided in Pedernales for over two years.

Sandra had not returned to Port-au-Prince since the earthquake. She told us that she would like to return to Pétionville to live there, but she feels that she cannot because "nothing has changed since the earthquake." In fact, Sandra firmly believes that change is not possible in Haiti. Part of her evidence is that, two years after the earthquake, authorities were still removing bodies from the rubble, and very little of the city had been reconstructed. Yet the basis of her pessimism lies not so much in the earthquake itself, but in Haiti and its people. When we asked her if she felt the government was to blame for Haiti's woes, she responded, "No, it's not so much Martelly [the President]. Haiti will never change because the people do not change." My fellow interviewer, Yoselyn Espinal, asked Sandra if she thought she had personally changed as a result of her experiences. "Yes," responded Sandra, "But I left Haiti." In her view, one has to leave Haiti in order to change: progress, whether personal or collective, cannot be found within this nation's borders, because Haitian society is governed by timeless processes. Sandra was by no means the only person we met who expressed this view: the majority of Haitians we interviewed expressed little or no belief that either their own locality or Haiti itself would - or could — change. In other words, the kinds of negative representations that are often imposed by outsiders are also reflected in the views of Haitian citizens. And yet, Haitians continue to strive to live modern lives, doing what they can to save time in order to consume it at their own leisure.

This perspective is interesting because it is at odds with both Daniel Miller's dualism and Aisha Khan's unfinished worlds. Sandra does not view Haiti as a world that is rapidly changing, such as in Miller's observations of Trinidad, or of a world that is not yet made, such as with creolization. Rather, she views Haitians as fixed in their character to such an extent that change is inconceivable. As such, her view resembles a kind of allochronism: while she does not deny Haitians contemporaneity with others per se, she does cast them as fixed in time while others move forward into the future. Furthermore, she ascribes a moralism 
to this Haitian character, inferring that change is positive, but not something that Haitians are capable of. Hence her representation of the Haitian character does not possess the redeeming features of the "noble savage" either. Neither modern, nor primitive, enmeshed neither in dualism, nor in creolization, it is as though her Haiti is stripped of time altogether.

Sandra places agency squarely onto Haitians for this predicament. The anthropologist Paul Farmer [2004] has a different point of view. In his work on structural violence, Farmer suggests that we take a "geographically broad" and "historically deep" view of Haiti to understand how structural factors have shaped contemporary Haiti. A history of domination, including slavery, reparations that France forced Haiti to pay for the loss of slaves after independence, US occupation, and structural readjustment have all contributed to a series of crises and worsened domestic ones such as political violence. Applying Paul Farmer's concept of structural violence, one could argue that Sandra's (and many other Haitians') view that Haiti cannot change are an outcome of the status of Haiti as a marginal outpost of empire. In other words, political-economic factors have historically been central to shaping Haiti, and they also shape the experience of time.

\section{- Production across national borders}

Perhaps nowhere in Hispaniola are temporal categories so ethnographically visible as on the border of the Dominican Republic and Haiti. Because it is an isolated region with relatively little tourism or other forces that perpetuate myths of a pristine island, representations of time are eclipsed by everyday practicalities and strategies to carve out lives and livelihoods. The meeting of the two nations, with their different administrative, economic, and cultural features, grants temporal categories and rhythms a particular salience as lived experience rather than as representation. Thousands of Haitians cross the border into the Dominican Republic daily to sell products or their labour, to use services not available in Haiti, and to buy commodities. Their ability to cross the border makes their lives easier, but it also exposes them to long-standing problems of discrimination and inequality [Derby and Turits, 1993; Martínez, 1995, 1999; Wucker, 1999]. Haitians' dependence upon Dominican markets means that the rhythms of their everyday lives are governed as much by Dominican temporal regimes-border opening hours, working schedules, pay cycles-as they are by Haitian ones.

As an ethnographer researching Haitian-Dominican relations, examination of temporal rhythms was a key tool in understanding the freedoms and restrictions that Haitians face as they struggle to carve out their lives vis-à-vis their Dominican neighbours. I conducted research on the southernmost point of the Dominican-Haitian border, in the towns of Pedernales (Dominican Republic) and Anse-à-Pitres (Haiti). These two towns are located just one kilometre apart and are a major trading node between the two countries. While Haitian-Dominican relations have historically been tense, residents of both sides of the border repeatedly told me that the two towns have always had amiable relations since they were founded nearly a hundred years ago. Echoing Adam Smith, they claim that their good relations exist because they trade with each other. Indeed, the economic relationship between the two towns is a major feature structuring temporal cycles and life experiences of Dominicans and Haitians living in the region.

One particularly important feature of the border region is the measurement of time as legislated by state administration. There is often, but not always, a time difference between the two nations, as Haiti is one time zone behind the Dominican Republic. Generally speaking, when Haitians and Dominicans speak about clock time, they default to the Dominican time zone. This reflects the far greater amount of time that Haitians spend in the Dominican Republic. Whereas Haitians cross the border daily to work, trade, and socialize, Dominicans rarely cross the border into Haiti and thus have little need or opportunity to adapt their consciousness of clock time. However, Haiti observed summer time from March 11, 2012, to November 4, 2012, in order to put it on par with Eastern Time in the United States. This placed it in the same time zone as the Dominican Republic because the latter does not observe summer time. This clock adjustment took place during our fieldwork, making organising interviews a challenge. My team and I were staying in Pedernales on the Dominican side of the border, and when we turned up to one interview in Anse-à-Pitres at the appointed time of nine o'clock in the morning (Haitian time), our interviewee was still asleep. Although the clocks had changed one week earlier, she was not aware of the adjustment, and still thought that Haiti was one hour behind the Dominican Republic. 
Her mobile phone, which she carried everywhere around her neck, did not automatically adjust the time. Another interviewee told me that the reason why the Haitian authorities decided to adjust summer time was to make the lives of American NGO workers simpler. In both cases, it appeared that official clock time was altered for the convenience of others, and it fell to ordinary Haitians to adjust their temporal routines.

Haitians living on the Dominican border depend upon the temporal regimes of foreigners on a daily basis, particularly as timetables affect when Haitians cross the border. Unlike at Jimaní, the major border crossing located a hundred kilometres to the north, the checkpoint at Pedernales and Anse-à-Pitres allows undocumented crossing, so long as one is not intending to travel beyond the two towns [Martínez, 1995, 1999]. The border is open daily from eight o'clock in the morning until six o'clock in the evening. Anyone wishing to traverse the administrative line separating the two nations can walk over a footbridge that spans the tree-lined Pedernales River and pass through a flimsy wire gate. A concrete footbridge spans the river, and in the dry season it is possible to walk, ride, or drive over the border through the riverbed.

Every day, dozens of residents of Anse-à-Pitres line up at the border to cross into the Dominican Republic. Some wait in the dry riverbed on motorbikes; most are on foot. Some carry bags or buckets on their

Trucks are a common way to travel around the country (Erin Taylor 2010).

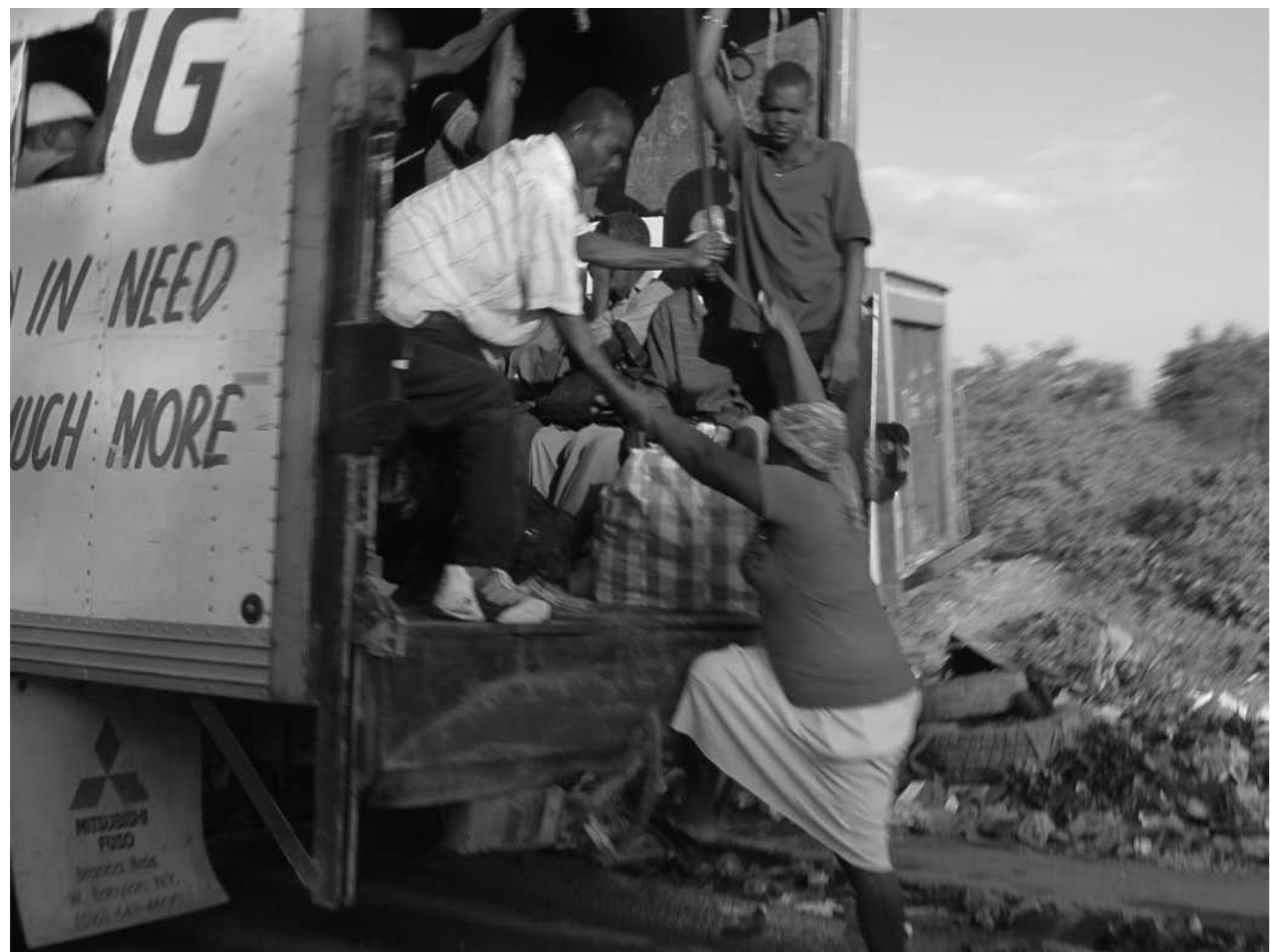


heads full of clothing accessories or fruits and vegetables that they will sell around the town of Pedernales. But most of the people waiting work as domestic servants and construction workers, for which they are paid wages that are far lower than those demanded by their Dominican counterparts. Many of the women waiting have already been awake for hours, arising at four o'clock in the morning to prepare lunch for their children, cooking outside their houses on fires made with carbon. In those early hours of the day they may also do the laundry, washing in buckets with water that runs past their houses in an open ditch. Residents of Anse-à-Pitres have few labour-saving devices, whether these are faster transport, a stove upon which to cook their family's lunch, or a washing machine. In contrast, Dominicans living in Pedernales are fully serviced with electricity and equipped with modern household goods, permitting them a great deal more time to relax with their friends and families. Without labour-saving devices, let alone the electricity to power them, domestic tasks lengthen the working day of Haitians considerably. When the Dominican guards open the border gates at seven o'clock, Haitians head for their jobs as employees of Dominicans, and most will not return to their homes in Haiti until the gates are about to close at six o'clock in the evening. Finally at home, they may have some leisure time, although numerous interviewees told me that "Haitian women never stop working." Indeed, it is rare to see people at rest, except for perhaps an afternoon siesta or a bout of gossip with neighbours in a yard.

Far from controlling the production of time, then, the time of Haitians is largely governed by the need to be constantly engaged in productive labour, either for themselves or others. They are dependent upon their Dominican neighbours, who not only dictate border opening hours and conditions for its crossing, but who are also their primary employers and set their work schedules. This brand of temporal modernity, in which hours of employment and pay cycles rather than agricultural labour and harvests come to structure the passing of time, is similar to that observed by Mintz [1985] for slaves in plantation society. Of course, Haitians have far more freedom than slaves to structure their daily lives and routines as they see fit, yet their ability to produce the temporal categories through which they practice socio-economic activities is similarly limited. This stark inequality in temporal freedom-with little autonomy to produce their own time-is indicative of Haiti's poverty and uneven modernity.

\section{- Times of mobility}

One of the major temporal cycles structuring life on the border is the bi-national market. Every Monday and Friday, dozens or even hundreds more people line up inside the gate to be let in to trade in an open-air market located just inside the Dominican border, right next to the river that separates the Dominican Republic from Haiti. On non-market days, Haitians entering the Dominican Republic are generally asked to pay a bribe of fifty pesos or gourdes (they are almost at par) to the Dominican guards, but entry is free on market days. Haitians from as far away as Jacmel (80 kilometres) and Dominicans from as far as the Samaná Peninsula (450 kilometres) converge upon this small, isolated corner of the island to trade. Dominican traders are almost always men who bring agricultural produce in large trucks to sell wholesale to Haitian buyers, who then export the goods across the border to Haiti. Coconuts and rice are particularly lucrative as they are in high demand in Haitian markets. The majority of Haitian traders are women who sell clothing, accessories, and shoes that they purchase in Port-au-Prince, or fruits and vegetables that are grown in the surrounding countryside. Some Haitian men sell electronic goods, including as televisions and mobile phones. These are usually brought to the border from Jacmel or Port-au-Prince.

Commerce not only structures the working week, but also the timetables of transport connecting Anse-à-Pitres to the rest of Haiti. Twice per week, on market days, a fleet of open fishing boats, equipped with outboard motors, travels sixty kilometres from Anse-à-Pitres to Marigot in Haiti's south. While the boats prepare to depart they weigh anchor just off Anse-à-Pitres's main beach. There is no wharf, so male Haitian labourers must carry all of the goods and passengers that will make the journey from the beach to the boats. They spend all day filling the boat's hold with commodities. When the sun is setting, travellers begin to converge on the beach as they wait for departure, having already paid the 250 gourdes (US\$6) fee for the journey.

The boats finally depart at around nine o'clock at night, and arrive in Marigot at four o'clock in the morning. Taptaps (Haitian buses made from converted pick-up trucks) wait to take ongoing passengers to their destinations. I made this boat trip once, back in 2005 , and it very much felt like a journey conducted in a different type of time. The slow pace of the boat, the lapping of waves, the moon shining above the hills on shore, the quiet chatter of passengers, and the 


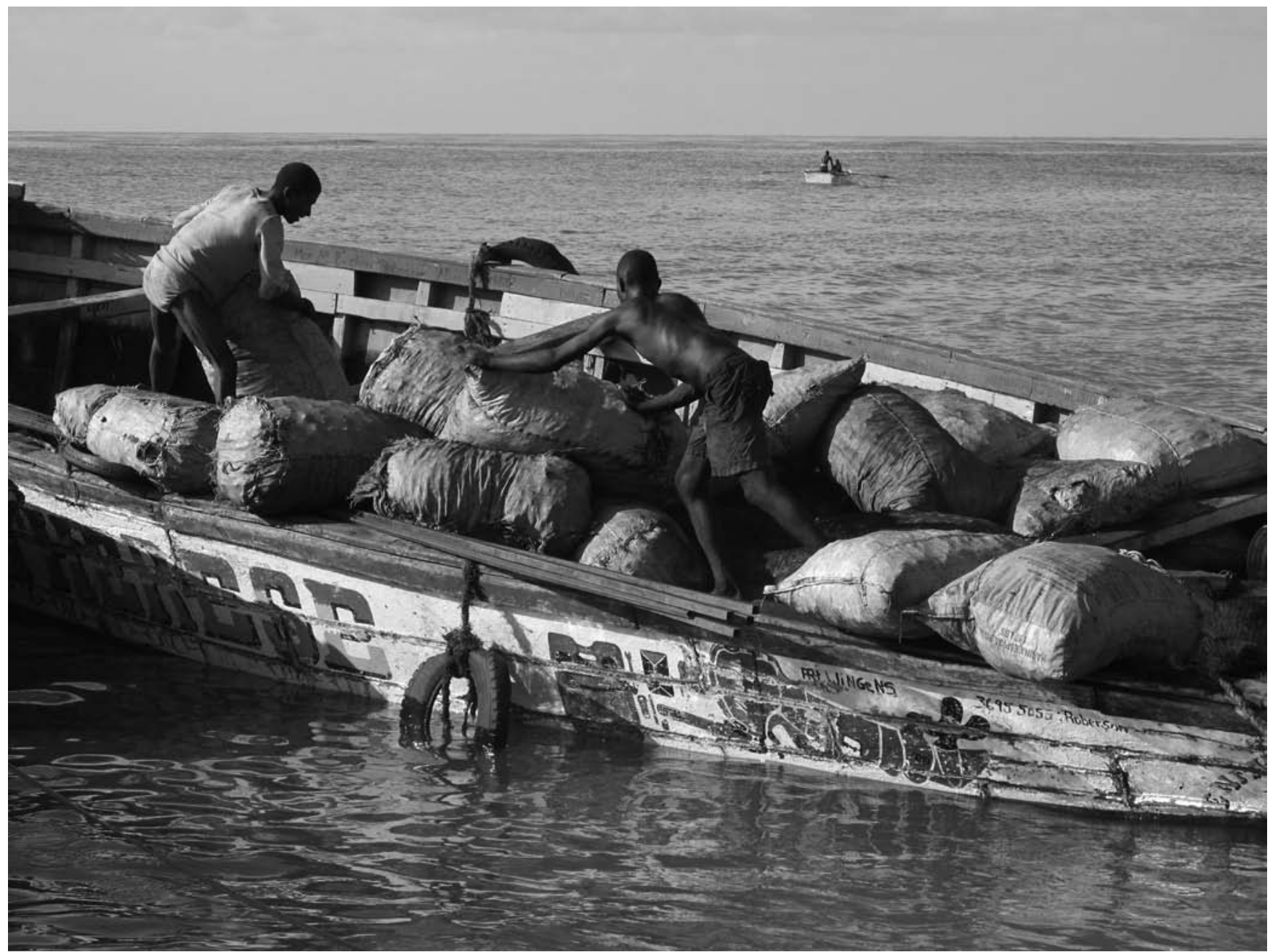

People, goods and cash travel on boats between Marigot and Anse-à-Pitres (Erin Taylor 2010).

melodious working songs of the boat's crew, all created an impression that time had slowed down. While motorised transport such as these boats is most certainly modern, the style of travel is phenomenologically distinct to other kinds of transport options that Haitians have available. Motorcycle taxis will make the journey from Anse-à-Pitres to Marigot, but bad roads mean that the distance is more than twice as far as by boat: 125 kilometres by road, versus 60 kilometres by sea. It is also far more expensive, at 800-1000 gourdes (US\$18-23) for the motorbike trip. Of course, by bike the trip takes far less time as it only takes around three hours, versus seven hours on a boat. But in Haiti, poverty means that it can be difficult to find enough cash to buy time. There is certainly more money to invest in time than there was in the past: it is not so many years since Haitians would walk for up to five days to bring their produce to market in the Dominican Republic, and walking trails still criss-cross the countryside to service many people who walk shorter distances to work and trade.

There are, however, other forms of consumption that Haitians can afford and which allow residents to save time. Chief among these is the mobile phone. The mobile is just one of many recent tools that humans have adopted to overcome the restrictions of space and time, having been preceded by shipping, forms of land transport, the aeroplane, the telegraph, and money transfer 
services. The mobile phone occupies a prominent place among these objects of mobility because it can act as a proxy for its users, freeing up time for economic and leisure activities or allowing the completion of tasks that would otherwise be impossible. Barely known in the border region less than a decade ago, the mobile phone plays a crucial role in helping families who are scattered across both sides of the national border stay in touch with their friends and family, thus enabling emotional support as well as facilitating economic livelihood.

Given the mobile phone's ability to transgress and compress space and time, it can effectively perform acts of mobility on behalf of users. Numerous interviewees, when we asked them to recount a time when the mobile helped them, described a moment in which ownership of a phone saved them the trouble of travelling somewhere in person. For example, Luis, who normally operates a motorcycle taxi, has a side-business selling mobile phones. He has relatives in Port-au-Prince and travels there approximately once per month to buy between five and seven Blu phones, which he then resells to the military working in the United Nations camp in Anse-à-Pitres. Sometimes he calls the store and places an order rather than travelling himself, in which case the phones are sent to him by bus. While Luis does not consider this option to be entirely safe (he is concerned about theft), it saves him two days of travel time and transport fares. Luis can therefore spend this time

A camp for earthquake refugees north of Port-au-Prince (Erin Taylor 2010).

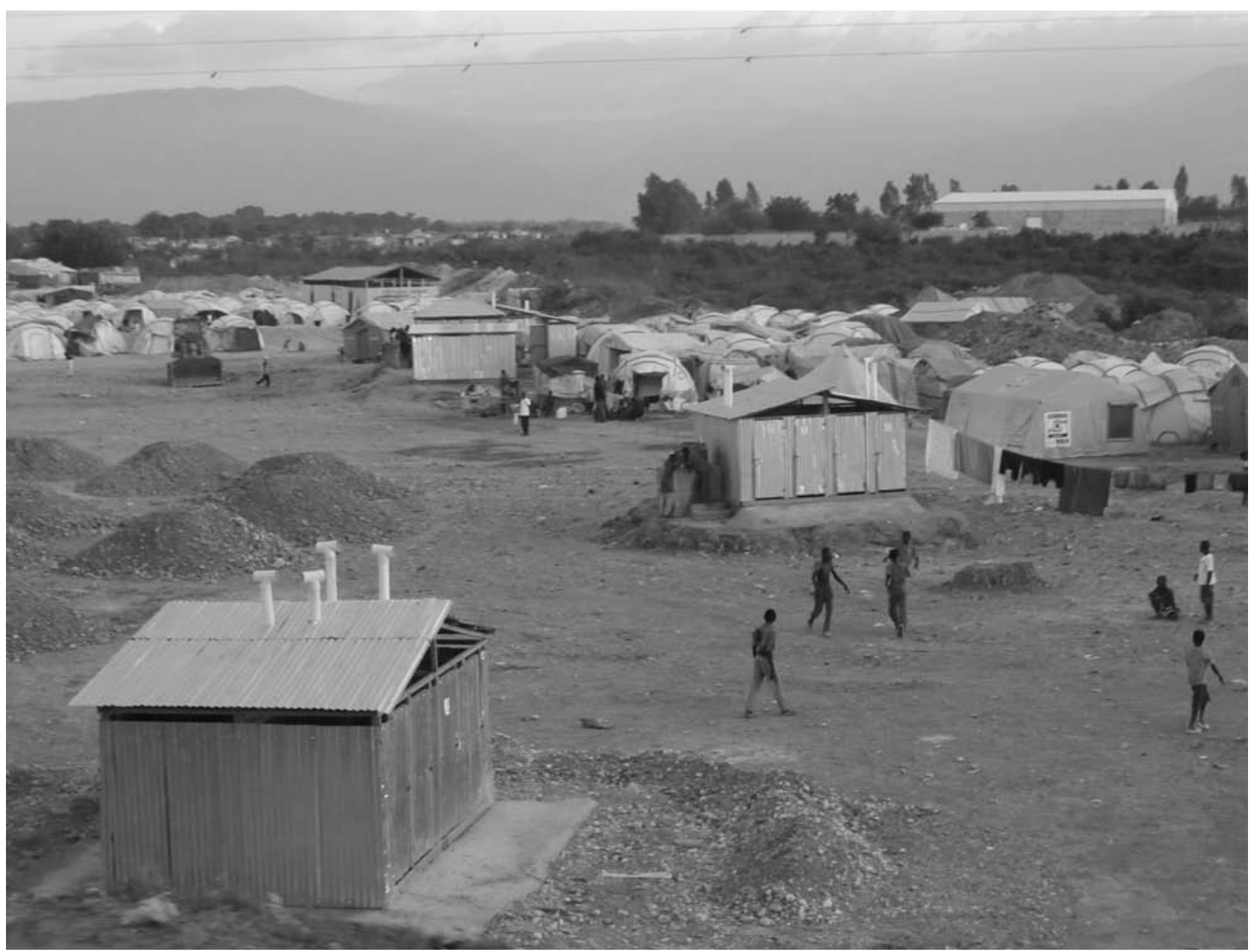


working on the border with his motorcycle. He changes his mobile handset every few weeks because he uses the Blu phones while he is trying to sell them, but he retains his own SIM card. This is crucial to his employment as his clients will call him to pick them up.

While the mobile phone's abilities to compress time are visible everywhere around the world, they are particularly useful in the border context, where underdeveloped infrastructures and significant bureaucratic obstacles mean that many activities take longer than usual to achieve. Indeed, the need to resolve problems quickly takes on a particular salience in Haiti, where natural or political crises regularly threaten to disrupt the flow of daily life and inhibit change.

\section{Times of crisis}

While daily routines are structured largely by productive activities and streamlined via the use of mobile phones and other kinds of time-saving objects, experiences of time are also affected by unusual events. At various moments, the ability of Haitians to cope with crises has been dependent upon whether the Dominican-Haitian border is open or closed. At times it has been shut down entirely, posing a major barrier for Haitians who require access in order to work or consume. Actions by the Haitian state to shut down the border are rare, generally only occurring during elections or other moments when political unrest is expected. Even then, not all border crossings are necessarily shut. When I was conducting fieldwork in Port-au-Prince in February 2011, due to a trade dispute, but the crossing at Anse-à-Pitres remained open. This reflects the latter town's isolation from major centres, as travel from the border to Port-au-Prince through Haiti is difficult by road.

It is far more common for the Dominican state to close the border's checkpoints than for the Haitian state to initiate a shut-down. After the earthquake, thousands of Haitians are reported to have crossed into the Dominican Republic at Jimaní, Pedernales, and other checkpoints. At first, the Dominican state responded positively to Haitian refugees from cities and towns that had been flattened in the earthquake. Camps were set up at Jimaní, and many Haitians stayed with family and friend dispersed throughout the Dominican Republic. In October 2010, however, the Dominican Republic closed the border in response to an outbreak of cholera in Haiti. Stevenson, one of our interviewees, claimed that the border was closed for three months (although we did not get a consistent answer from our interviewees). He and his wife have a stall in the market where they sell sandals and items of clothing. When I asked him what he did to cope, he replied, "Nothing. The border was shut, there was nothing we could do, so we stayed at home." No possibility to cross into the Dominican Republic meant that neither Stevenson nor his wife could work to support their young family. Instead, they depended upon friends and family for support.

The Haitian-Dominican border at Anse-a-Pitres and Pedernales (Erin Taylor 2010).

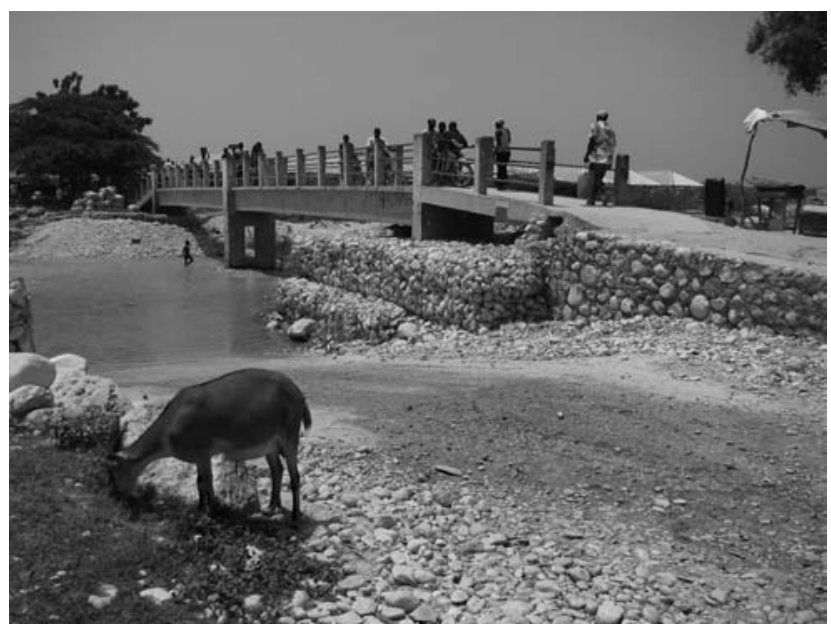

Customers chat while riding a Haitian taptap (Erin Taylor 2010).

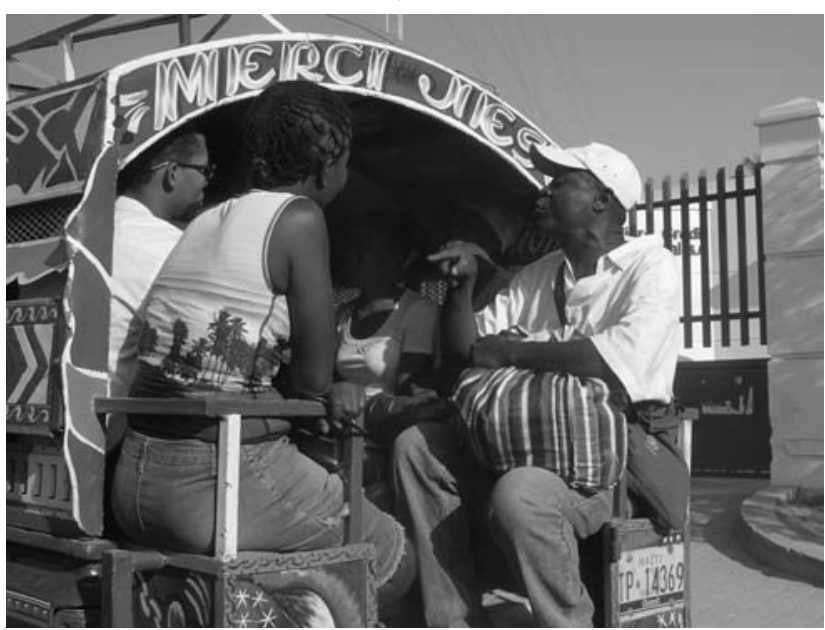


This arrest by the state is the flip side of the coin to Sandra's situation. She migrated to the border because "Haiti will never change." Unlike most migrants, she was eventually able to obtain a Dominican visa because she had the money to pay for one. Stevenson trades on the border because his livelihood depends upon selling in the wealthier Dominican market, yet his ability to do so is dependent upon the Dominican state. He lacks the resources to secure his livelihood by changing his residency from one state to another, and indeed, may not wish to do so. Far from waiting for social change resulting from increased investment or aid from the international community, or through a change in government, he and his family live with the expectation of more crises. His family have mitigated risk by building a small house and stocking up on goods that they can trade within Haiti as well as in the Dominican Republic. They maintain their social connections over wide geographical distances, especially through the mobile phone, as these can be critical to sitting out crises.

These kinds of investments in the material world buffer the impact of crises and make an important contribution to perceptions of time: they may not increase people's belief that things will change significantly in the future, but they at least prevent a sense of sliding backwards, of losing what they have gained over time. For people living in precarious circumstances, this is the stuff of life, because it is what enables people to gain sufficient security to maintain sustenance and reproduce their social life through their family. After all, one could argue that the most relevant kind of time is that which brings forth new generations.

\section{- Towards an historical consciousness of Caribban rhythms}

The ethnographer investigating time in the Caribbean is faced with a plethora of choices. The allochrony that pervades many popular representations has important political consequences, both positive and negative, in fuelling economic growth or limiting sovereignty. In anthropology, the Caribbean has been adopted as a locus for discussions of broader temporal processes, including tradition, creolization, modernity, and globalization. Yet little has been written about how temporal rhythms are created and experienced by Caribbean people.

One can surmise that this is because many aspects of these rhythms are created at a level of social structure that is a far broader level, including state (such as legislating time changes or border opening hours), or interstate (such as modernity). However, ethnographies of these more abstract experiences of time, such as Miller's work on modernity in Trinidad, show how understanding local life in this context is indeed possible. My research supports Miller's in demonstrating how modernity and tradition are experienced through everyday activities, such as border crossings or economic cycles, and in the course of unusual events, such as earthquakes or political crises.

My analysis diverges from Miller's in focusing on the role of productive activities in shaping people's relationships with time. Furthermore, consumption has its limitations: Haitians who are poor cannot afford to buy labour-saving devices that would free up their leisure time, nor can they pay to reside in the Dominican Republic to avoid having to navigate the border's timetable. Even people who command greater resources and have been able to move across the border, such as Sandra and her family, struggle to see beyond the notion that Haiti is stuck in a repeating cycle with no chance of improvement. It would seem that, sometimes, allochrony wins the game in dominating representations. Nevertheless, Haitians continue upon the long march of modernity, deploying whatever resources they can command to produce the kind of time they wish to live in as they struggle to at least stand still in the flowing stream of time. Their persistence with this task has a long historical pedigree.

\section{Note}

This research was funded by the Institute for Money, Technology and Financial Inclusion at the University of California, Irvine, and carried out with Dr. Heather Horst. Thanks to Bill Maurer, Jenny Fan, Mariko Oda and Yoselyn Espinal for support and assistance throughout the project. 


\section{References}

Andrade Manuel Jose, 1969, Folklore from the Dominican Republic, New York, Kraus Reprint Co.

Berman Marshall, 1982, All That Is Solid Melts Into Air, New York and London, Penguin Books.

Derby Lauren and Richard tURITS, 1993, "Historias de terror y los terrores de la historia: la masacre haitiana de 1937 en la República Dominicana”, Estudios Sociales, XXVI, 92: 65-76.

Fabian Johannes, 1983, Time and the Other: How Anthropology Makes its Object, New York, Colombia University Press.

Farmer Paul, 2004, "An Anthropology of Structural Violence", Current Anthropology, 45, 3: 305-325.

Farmer Paul, 2012, Haiti After the Earthquake, New York, Public Affairs.

GLICK sCHILler Nina and Georges Eugene Fouron, 2001, Georges Woke Up Laughing: Long-Distance Nationalism and the Search for Home, Durham and London, Duke University Press.

Gregory Steven, 2007, The Devil Behind the Mirror: Globalization and Politics in the Dominican Republic, Berkeley, University of California Press.

Herskovits Melville, 1937, Life in a Haitian Valley, New York, Anchor Books.

Herskovits Melville, 1938, Acculturation: The Study of Culture Contact, New York, JJ Augustin.

Herskovits Melville, 1972, Cultural Relativism: Perspectives in Cultural Pluralism, New York, Random House.

Horst Heather and Daniel Miller, 2006, The Cell Phone: An Anthropology of Communication, New York, Berg.

Hurston Zora Neale, 2009, Tell My Horse: Voodoo and Life in Haiti and Jamaica, HarperCollins e-books.
Khan Aisha, 2001, "Journey to the Center of the Earth: The Caribbean as Master Symbol", Cultural Anthropology, 16, 3: 271-302.

Khan Aisha, 2004, Callaloo Nation: Metaphors of Race and Religious Identity among South Asians in Trinidad, Durham and London, Duke University Press.

Martínez Samuel, 1995, Peripheral Migrants: Haitians and Dominican Republic Sugar Plantations, Knoxville, University of Tennessee Press.

Martínez Samuel, 1999, "From Hidden Hand to Heavy Hand: Sugar, the State, and Migrant Labor in Haiti and the Dominican Republic", Latin American Research Review, 34, 1: 57-84.

Mintz Sidney, 1962, "Living Fences in the Fond-des-Nègres Region, Haiti", Economic Botany, 16, 2: 101-105.

Mintz Sidney, 1979, “The Rural Proletariat and the Problem of the Rural Proletarian Consciousness", in Robin Cohen, Peter Gutkind and Phyllis Brazier (eds.), Peasants and Proletarians: The Struggles of Third World Workers, London, Hutchinson and Co. Ltd: 173-197.

Mintz Sidney and Sally Price (eds.), 1985, Caribbean Contours, Baltimore and London, The John Hopkins University Press.

SCHuller Mark, and Pablo Morales (eds.), 2012, Tectonic shifts: Haiti Since the Earthquake. Sterling, VA, Kumarian Press.

Trouillot Michel-Rolph, 1995, Silencing the Past: Power and the Production of History, Boston, Beacon Press.

Troulllot Michel-Rolph, 2003, Global Transformations: Anthropology and the Modern World, New York, Palgrave MacMillan.

Wucker Michelle, 1999, Why the Cocks Fight: Dominicans, Haitians, and the Struggle for Hispaniola, New York, Hill and Wang. Yelvington Kevin, 1995, Producing Power: Ethnicity, Gender, and Class in a Caribbean Workplace, Philadelphia, Temple University Press.

\section{IBSTRACT}

\section{When crisis is experienced as continuity. Materialities of time in Haiti}

This paper explores various ways in which time is experienced and practiced by Haitians living on the Dominican-Haitian border. By examining different kinds of temporal practices and viewpoints, the author questions the assumption that the earthquake of January 2010 has brought a significant break with the past and shows that rather than an isolated and unique rupture, crisis is a relatively constant feature of historical experience. The ways that people communicate their biographies and imagine their futures reflect this temporal continuity.

Keywords: Time. Modernity. Caraibs. Crisis. Haiti.

\section{ZUSAMMENFASSUNG}

\section{Die Krisenerfahrung als Kontinuität. Die materielle Nutzung von Zeit in Haiti.}

Dieser Artikel untersucht die Art und Weise mit der Zeit von den Haitianern, die an der Grenze zur Dominikanischen Republik wohnen, erlebt und genutzt wird. Durch die Untersuchung verschiedener Formen temporaler Praktiken und die Darstellungen, die mit ihnen verbunden sind, hinterfragt der Autor die Annahme, dass das Erdbeben im Januar 2010 einen brutalen Bruch mit der Vergangenheit darstellt. Er zeigt auf, dass die Krise in Haiti kein einzigartiger historischer Einschnitt ist, sondern eine konstante Charakterisik der historischen Erfahrung. Die Art und Weise in der die persönlichen Biographien erzählt werden und die angestrebte Zukunft reflektieren diese Kontinuitäten.

Stichwörter: Zeit. Modernität. Karibik. Krise. Haiti. 